\title{
PENDEKATAN VIKTIMOLOGI KONSEP RESTORATIVE JUSTICE ATAS PENETAPAN SANKSI DAN MANFAATNYA BAGI KORBAN KEJAHATAN LINGKUNGAN
}

\author{
Dewi Setyowati \\ Fakultas Hukum Universitas Hang Tuah, Surabaya \\ Email : dewi.setyowati@hangtuah.ac.id
}

\begin{abstract}
ABSTRAK
Pusat perhatian keadilan restoratif adalah pemberdayaan, partisipasi dan penyembuhan korban kejahatan. Sampai saat ini, keadilan restoratif hanya digunakan untuk kejahatan yang sifatnya konvensional atau kejahatan ringan. Namun jarang, digunakan untuk kejahatan lingkungan. Padahal pendekatan dan manfaat dari restorative justice memiliki potensi untuk lebih sering digunakan dalam menangani kejahatan lingkungan. Dalam masalah ini, penyelesaian sengketa lingkungan hidup maupun penegakan hukum pidana bukan prioritas pertama. Prioritas pertama adalah penanggulangan dan pemulihan. Jika pemerintah melalui Kementerian Lingkungan Hidup dan Kehutanan (KLHK) ingin berupaya maksimal menangani masalah ini, penting memikirkan strategi penempatan upaya penegakan hukum agar sinkron dengan penanggulangan dan pemulihan. Pemanfaatan konsep restorative justice dengan menguraikan manfaat penerapannya terhadap penyelesaian kejahatan lingkungan. Mengidentifikasi korban kejahatan lingkungan dan cara mereka mampu berpartisipasi dalam proses restoratif. Secara khusus, memperhatikan ide-ide masyarakat yang lebih luas, keberlangsungan generasi masa depan dan lingkungan hidup yang lebih baik. Artikel ini mengeksplorasi jenis-jenis hasil keadilan restoratif yang tersedia, termasuk reparasi, restitusi dan kompensasi atas terjadinya kerusakan lingkungan. Dengan menerapkan proses restoratif terhadap kejahatan lingkungan, restorative justice dapat bersifat transformatif bagi korban, pelaku, masyarakat, lingkungan dan sistem peradilan pidana sehingga memungkinkan hasil yang lebih adil untuk kasus kejahatan lingkungan.
\end{abstract}

Kata Kunci : sanksi, viktimologi, restorative justice, lingkungan.

\section{ABSTRACT}

The focus of restorative justice is the empowerment, participation and healing of victims of crime. Until now, restorative justice has only been used for crimes of a conventional nature or minor crime. But rarely, it is used for environmental crime. Even though the approach and benefits of restorative justice have the potential to be used more often in dealing with environmental crime. In this matter, settlement of environmental disputes and enforcement of criminal law are not the first priority. The first priority is prevention and recovery. If the government through the Ministry of Environment and Forestry (KLHK) wants to make the maximum effort to deal with this problem, it is important to think of a strategy to place law enforcement efforts to synchronize with mitigation and recovery. Utilizing the concept of restorative justice by outlining the benefits of its application to the resolution of environmental crime. Identify victims of environmental crime and how they can participate in restorative processes. In particular, paying attention to the ideas of the wider community, the sustainability of 
future generations and a better environment. This article explores the types of restorative justice available, including reparations, restitution and compensation for environmental damage. By implementing a restorative process on environmental crime, restorative justice can be transformative for victims, perpetrators, society, the environment and the criminal justice system so as to enable more equitable outcomes for environmental crime cases.

Keywords: sanctions, victimization, restorative justice, environment.

\section{Pendahuluan}

Jika dilihat berdasarkan PP Nomor 19/1999, pencemaran laut diartikan sebagai masuknya/dimasukkannya makhluk hidup, zat, energi, dan/atau komponen lain ke dalam lingkungan laut oleh kegiatan manusia, sehingga kualitas laut turun sampai ke tingkat tertentu yang menyebabkan lingkungan laut tidak sesuai lagi dengan baku mutu dan/atau fungsinya.

Pencemaran laut erat kaitannya dengan aktivitas manusia yang disertai dengan kemajuan teknologi. Salah satu sumber pencemaran laut adalah aktivitas pengeboran minyak di lepas pantai atau yang disebut dengan offshore. Di Indonesia perusahaan minyak yang memiliki dan mengoperasikan pengeboran minyak lepas pantai; diantaranya: Conoco Philips, CNOOC, Chevron, Pertamina dan Medco.

Kejadian tumpahan minyak ke laut (oil spill) terjadi pada saat terjadi pelepasan cairan minyak hidrokarbon ke dalam lingkungan laut. Tumpahan ini dapat berasal dari docking (perbaikan/perawatan kapal), tank cleaning (pembersihan tanki minyak), scrapping kapal (pemotongan badan kapal untuk menjadi besi tua), kecelakaan tanker (kebocoran lambung, kandas, ledakan, kebakaran dan tabrakan), atau illegal bilge yaitu saluran buangan air, minyak dan pelumas hasil proses mesin yang merupakan limbah ke laut.

Limbah buangan minyak lepas pantai umumnya berasal dari hasil eksplorasi produksi minyak, pemeliharaan fasilitas produksi, fasilitas penyimpanan, pemrosesan dan tanki penyimpanan minyak pada kapal laut. Salah satu kejadian spektakuler cemaran laut oleh tumpahan minyak terjadi saat supertanker Exxon Valdez menabrak karang di Teluk Prince William, lepas pantai Alaska pada 24 maret 1989. Akibatnya sekitar 11 juta galon minyak mencemari laut yang berakibat buruk pada biota laut, seperti paus orca.

Limbah minyak sendiri berasal dari minyak mentah (crude oil) yang memiliki ribuan konstituen pembentuk yang secara struktur kimia terdiri dari lima famili, yaitu: saturated hydrocarbons, aromatics, asphalten dan resin, porphyrine, dan komponen nonhidrokarbon. Karena sifatnya yang berupa bahan beracun berbahaya dan beracun (B3), limbah minyak dalam suatu konsentrasi tertentu dan jumlahnya dapat menjadi bahan pencemar dan membahayakan lingkungan hidup. Limbah minyak dapat menyebabkan infeksi dan keracunan bagi manusia. Bagi lingkungan bahan ini dapat menimbulkan korosif, sangat mudah terbakar dan bahkan sangat mudah meledak. 
Offshore atau pengeboran minyak lepas pantai juga sering "menyumbang" cemaran minyak mentah ke laut. Oil spill pada upaya offshore atau platform banyak menjadi penyebab terjadiinya ledakan (blowout) yaitu pada saat fluida di sumur mengalami kondisi out of control. Fluida tersebut menyembur keluar dari sumur bor pada saat dilakukannya proses pengeboran (drilling). Fenomena ledakan yang luar biasa pernah terjadi di Deepwater Horizon Mocondo 252 Teluk Meksiko pada tanggal 20 April 2010, hingga menyebabkan platform tenggelam ke dasar laut. Pemerintah AS memperkirakan total tumpahan minyak sebesar 4,9 juta barel. Dilaporkan hingga awal tahun 2012, masih terjadi kebocoran minyak di sumur pemboran. Bisa dibayangkan berapa besar kerusakan habitat laut dan kerugian berbagai sektor ekonomi akibat dampak buruk teknologi tersebut. Oil spill pada offshore juga sering terjadi bila terjadi kebocoran di saat production tubing, yaitu saat dilakukannya perpindahan cairan dari producing formation ke christmas tree/wellhead.

Resiko ini juga meningkat sejalan dengan turunnya harga minyak dunia. Penghematan yang dilakukan oleh perusahan minyak untuk komponen pemeliharaan katup (valve maintenance) yang mahal, kerap dilakukan oleh perusahaan untuk menyiasati berbagai biaya pengeluaran saat harga minyak jatuh. Untuk mengantisipasi dampak buruk pencemaran minyak di laut akibat terjadinya oil spill, secara internasional negara-negara di dunia mengadakan konvensi internasional yang selanjutnya diturunkan dalam aturan di tiap negara. Diantaranya, disepakati aturan-aturan tentang pencemaran laut dalam konvensi PBB 1958 tentang Laut Lepas yang memasukkan dua ketentuan terkait pencemaran laut, aturan lain relevan adalah Konvensi Hukum Laut 1982.

Dalam hukum nasional, aturan terkait ini dituangkan dalam UU Nomor 23/1997 tentang Pengelolaan Lingkungan Hidup dan UU Nomor 17/2008 tentang Pelayaran. Turunan UU diatas, diantaranya adalah Peraturan Pemerintah (PP) Nomor 19/1999 tentang Pengendalian Pencemaran dan atau Perusakan Laut, Peraturan Presiden Nomor 109/2006 tentang Penanggulangan Keadaan Darurat Tumpahan Minyak di Laut. Juga Peraturan Pemerintah RI Nomor 20/1990 tentang Pengendalian Pencemaran Air.

Tujuan dari adanya berbagai UU dan aturan ini ditujukan agar para pemangku kepentingan, secara khusus perusahaan migas dapat terus-menerus mengembangkan kemampuan Health, Safety and Environment (HSE). Hal ini tak lepas dari tanggung jawab perusahaan untuk menjamin tidak terjadinyaoil spill dan berbagai bentuk upaya pencemaran minyak lain di laut, yang dapat merugikan lingkungan maupun sosial-ekonomi masyarakat.

Di sisi lain, banyak teknik yang dapat dijalankan untuk meminimalisir dampak cemaran dan tumpahan minyak, seperti oil booms, in-situ burning, skimmer, bioremediasi (agen biologis penghapus minyak), mekanisme adsorpsi, dispersan kimiawi, atau dengan memecah lapisan minyak dengan boat kecepatan tinggi. 
Diharapkan semoga perusahaan minyak lepas pantai, khususnya di Indonesia peduli dengan kelestarian laut dan keselamatan biotanya. Faktanya, wilayah laut Indonesia masih sering mengalami pencemaran akibat tumpahan minyak, diantara kasus yang terbaru adalah tumpahnya minyak di Teluk Balikpapan tepatnya pada 31 Maret 2018. Saat itu, diduga tumpahan karena kegiatan salah satu perusahaan eksploitasi minyak-belakangan terungkap, kalau tumpahan minyak karena pipa bawah laut PT Pertamina, terputus. Minyak mentah pun tumpah mengotori laut. Sangat disayangkan, informasi resmi mengenai kronologis peristiwa ini termasuk siapa pihak bertanggungjawab tidak disampaikan segera kepada publik. Malah, terlebih dahulu beredar informasi tak resmi mengenai dampak tumpahan minyak yang menguraikan ada korban jiwa, kerugian lingkungan dan kerugian masyarakat

(http:/ / www.mongabay.co.id).

Mengacu Pasal 53, ayat 2 huruf a Undang-undang Nomor 32 Tahun 2009 (selanjutnya disebut UU 32/2009), pemberian informasi kepada masyarakat merupakan salah satu langkah dalam upaya penanggulangan. Selain penyampaian informasi resmi cepat dan tepat, setidaknya ada tiga langkah lain perlu dilakukan pemerintah dalam menangani kasus ini. Pertama, memastikan pihak bertanggungjawab melakukan penanggulangan atau jika belum dapat ditentukan, pemerintah terlebih dahulu melakukan penanggulangan. Kedua, memastikan pihak yang bertanggungjawab untuk pemulihan lingkungan. Ketiga, upaya penegakan hukum yang bersifat melengkapi kedua poin sebelumnya. Kedua langkah pertama merupakan prioritas pertama, sedangkan langkah terakhir sebagai prioritas kedua.

Jika penanggulangan dan pemulihan sebagai prioritas pertama telah berjalan namun masih ada biaya belum dikompensasi, dapat ditempuh penyelesaian sengketa lingkungan hidup. Ia dapat dilakukan melalui dan di luar pengadilan. Contoh biaya ini antara lain, kompensasi karena hasil tangkapan nelayan berkurang, kompensasi berkurang wisatawan, kompensasi pemasukan usaha berkurang, dan kompensasi ekosistem tak terpulihkan. Lalu, biaya penilaian kerusakan sampai persidangan. Penyelesaian sengketa lingkungan hidup ini dapat dilakukan oleh pemerintah melalui Hak Gugat Menteri Lingkungan Hidup dan Kehutanan maupun oleh masyarakat yang mengalami kerugian.

Sedangkan penegakan hukum pidana harus digunakan untuk tujuan berbeda dengan penyelesaian sengketa lingkungan hidup. Dalam hal ini, pidana sebaiknya sebagai instrumen bersifat punitif, agar memberikan efek jera dan mencegah tindak pidana terulang. Tentu, sangat mungkin penggunaan pertanggungjawaban pidana korporasi selama syarat-syarat terpenuhi.

Keadilan restoratif adalah cara menangani kejahatan dengan menyeimbangkan kebutuhan masyarakat, korban dan pelaku. Hal tersebut merupakan solusi yang lebih holistik untuk berusaha memahami kejahatan dan 
mengatasi dinamika perilaku kriminal, penyebab dan konsekuensinya. Pusat perhatian keadilan restoratif adalah pemberdayaan, partisipasi dan penyembuhan korban kejahatan. Sampai saat ini, keadilan restoratif hanya digunakan untuk kejahatan yang sifatnya konvensional atau kejahatan ringan. Namun jarang, digunakan untuk kejahatan lingkungan. Padahal pendekatan dan manfaat dari restorative justice memiliki potensi untuk lebih sering digunakan dalam menangani kejahatan lingkungan.

Dalam masalah ini, penyelesaian sengketa lingkungan hidup maupun penegakan hukum pidana bukan prioritas pertama. Prioritas pertama adalah penanggulangan dan pemulihan. Jika pemerintah melalui Kementerian Lingkungan Hidup dan Kehutanan (KLHK) ingin berupaya maksimal menangani masalah ini, penting memikirkan strategi penempatan upaya penegakan hukum agar sinkron dengan penanggulangan dan pemulihan.

Pemanfaatan konsep restorative justice dengan menguraikan manfaat penerapannya terhadap penyelesaian kejahatan lingkungan. Mengidentifikasi korban kejahatan lingkungan dan cara mereka mampu berpartisipasi dalam proses restoratif. Secara khusus, memperhatikan ide-ide masyarakat yang lebih luas, keberlangsungan generasi masa depan dan lingkungan hidup yang lebih baik. Artikel ini mengeksplorasi jenisjenis hasil keadilan restoratif yang tersedia, termasuk reparasi, restitusi dan kompensasi atas terjadinya kerusakan lingkungan.

\section{Metode Penelitian}

Penelitian ini merupakan penelitian hukum (Legal Research), yang merupakan serangkaian tindakan atau proses untuk menemukan hukum disebabkan terjadinya kekosongan hukum (vacuum norm), kekaburan norm (obscuur norm) maupun konflik norm (conflict of norm) atau menemukan asas hukum, yang mengatur norma hukum yang mengikat secara umum dan dibentuk atau ditetapkan oleh lembaga atau pejabat yang berwenang melalui prosedur yang ditetapkan dalam peraturan perundang-undangan, khususnya yang berkenaan dengan norma yang mengatur sanksi yang berkeadilan restoratif.

\section{Pembahasan}

Perspektif viktimologi dalam mengkaji korban memberikan orientasi bagi kesejahteraan masyarakat, pembangunan kemanusiaan masyarakat, dalam upayanya untuk menjadikan para anggota masyarakat tidak menjadi korban dalam arti luas. Sebagaimana dikemukakan Mendelsohn bahwa : .... that victimology should be a separate and autonomous science, should have its own institutions and should be allowed to develop for the well-being and progress of humanity (Mendelsohn, 1974).

$\begin{array}{lrr}\text { Studi korban } & \text { dalam } \\ \text { viktimologi, memberikan } & \text { suatu } \\ \text { gagasan bidang jelajah } & \text { dalam } \\ \text { viktimologi yaitu: } & & \end{array}$
1. Konteks sosial yang menjadi tempat terjadinya viktimisasi. Konteks sosial menunjuk pada nilainilai kultural tradisi dan strukturstruktur yang mempengaruhi perbedaan, kedudukan, status 
individu atau kelompok seperti tekanan sosial. konflik, cap jahat, dan ketidak seimbangan struktural antara tujuan dan cara dari sistem sosial, peluang untuk melakukan jalan lain untuk memakai cara-cara yang ilegal dan untuk differential association ..., serta cara-cara penyelesaian konflik.

2. Akibat-akibat sosial dari viktimsasi yang dapat berpengaruh buruk terhadap individu tertentu, kelompok, masyarakat luas, maupun kemanusiaan pada umumnya baik secara medis, psikiatri, kriminologi dan implikasi sosial. Hal ini melibatkan problem tertentu dari perilaku kolektif, dalam proses yang sukar untuk dipahami karena masyarakat atau pemegang kekuasaan dari masyarakat adalah cukup peka untuk menentukan pengaruh buruk, sebagai problema masyarakat. Dengan kata lain pengaruh kuat mungkin eksis dan melekat dalam jangka waktu lama, tanpa atau belum dilihat dan dipublikasikan sebagai problematik (Dadrian, 1976).

Perkembangan viktimologi sebagai studi tentang korban dengan segala aspeknya pada awalnya merupakan daerah domonion dari kriminologi, dengan aspek dan faset kepidanaan atau kriminologi menjadi fokus perhatian. Dalam perkembangannya diakui mandiri sebagai suatu ilmu yang berdiri sendiri, sebagai ilmu baru di Indonesia yang dapat dipandang sebagai suatu terra incognita (Sahetapy, 1987).

Dalam merumuskan tindak pidana lingkungan ini, seperti dikemukakan Muladi hendaknya selalu diingat bahwa kerugian dan kerusakan lingkungan hidup tidak hanya yang bersifat nyata (actual harm), tetapi juga yang bersifat ancaman kerusakan potensial baik terhadap lingkungan hidup maupun kesehatan umum. Hal ini disebabkan karena kerusakan maupun kesehatan umum tersebut seringkali tidak seketika timbul dan tidak dengan mudah pula untuk dikualifikasi. Sehubungan dengan ini generic crime yang relatif berat sebaiknya memang dirumuskan sebagai tindak pidana materiil, dalam hal mana akibat merupakan unsur hakiki yang harus dibuktikan. Namun untuk tindak pidana yang bersifat khusus (specific crimes) yang melekat pada hukum administrasi dan relatif lebih ringan, maka perumusan yang bersifat formil tanpa menunggu pembuktian akibat yang terjadi dapat dilakukan (Muladi).

$$
\text { Restorative justice adalah }
$$
sebuah konsep pemikiran yang merespon pengembangan sistem peradilan pidana dengan menitikberatkan pada kebutuhan pelibatan masyarakat dan korban yang merasa tersisihkan dengan mekanisme yang bekerja pada sistem peradilan pidana yang ada pada saat ini. Dipihak lain, restorative justice juga merupakan suatu kerangka berfikir yang baru yang dapat digunakan dalam merespon suatu tindak pidana bagi penegak dan pekerja hukum. Penanganan perkara pidana dengan pendekatan restorative justice menawarkan pandangan dan pendekatan berbeda dalam memahami dan menangani suatu tindak pidana.

Tonny

Marshal mengemukakan Restorative Justice adalah "proses dimana para pihak yang terlibat dalam kejahatan secara 
bersama-sama menyelesaikan permasalahan yang berkaitan dengan bagaimana cara menghadapi permasalahan pasca kejahatan serta akibat-akibatnya di masa depan" (Ridwan Mansyur;2010). Raithwaite menyatakan bahwa Restorative Justice adalah "penyembuhan, pembelajaran moral, partisipasi dan perhatian masyarakat, dialog, rasa memaafkan, tanggungjawab dan membuat perubahan, yang semuanya itu merupakan pedoman bagi proses restorasi dalam perspekstif restorartive justice".

Tom Cavanagh menyatakan bahwa Restorative Justice adalah "respon yang sistematis atas tindak penyimpangan yang ditekankan pada pemulihan atas kerugian yang dialami korban dan atau masyarakat sebagai akibat dari perbuatan kriminal" (Tom Cavanagh). Menurut Mark Umbreit menyatakan bahwa : Restorative justice provides as verry different framework for undeersantanding and responding to crime. Crime in understood as harm to individuals and communities, rather than simply a violation of abstract laws against the state. Those most directly affected by crime - victims, community members and offenders - are therefore encouraged to play an active role in the justice process. Rahter than the current focus on offender punishment, restoration of the emotional and material losses resulting from crime is far mor important (Mark Umbreit).

Teresa

Cunningham mengemukakan Restorative Justice, "tujuan dari tanggungjawab restorasi bagi pelaku tindak pidana adalah untuk memfokuskan pada sikap pelaku di masa yang akan datang dan mengembalikan martabat dan harga diri korban, dengan cara demikian akan membangun kembali hubungan sosial". Crawford dan Newburn menyimpulkan bahwa Restorative Justice adalah restorasi, reintegrasi dan tanggungjawab. Howard Zehr mengemukakan

bahwa: "Restorative justice is a process to involve to the extent possible, those who have a stake in a specific offense and to collectively identify and address harms, needs, and obligation, in order to heal and put things as right as possible" (Howard Zehr;2002), (Terjemahan bebas : Restorative Justice adalah proses melibatkan mereka yang berkepetingan secara obligasi untuk menyembuhkan sesuatu yang benar pada tempatnya).

Dalam Handbook on Restorative Justice Programmes menyebutkan, bahwa: Restorative justice is an approach to problem solving that, in its various forms, involves the victim, the offender, their social networks, justice agencies an the community (United Nations, Handbook on Restorative Justice Programmes). (Terjemahan: Restorative justice adalah sebuah pendekatan untuk pemecahan masalah dalam berbagai bentuk, melibatkan korban, pelaku, jaringan sosial, lembaga-lembaga keadilan dan masyarakat).

Tidaklah mudah memberikan definisi bagi pendekatan restorative justice ini, mengingat banyaknya variasi model dan bentuk yang berkembang dalam penerapannya. Dalam pandangan restorative justice makna tindak pidana pada dasarnya sama seperti pandangan hukum pidana pada umumnya yaitu serangan terhadap individu dan masyarakat serta hubungan kemasyarakatan. Akan tetapi dalam pendekatan restorative justice, 
korban utama atas terjadinya suatu tindak pidana bukanlah negara, sebagaimana dalam sistem peradilan pidana yang sekarang ada. Oleh karenanya kejahatan menciptakan kewajiban untuk membenahi rusaknya hubungan akibat terjadinya suatu tindak pidana. Sementara keadilan dimaknai sebagai proses pencarian pemecahan masalah yang terjadi atas suatu perkara pidana dimana keterlibatan korban, masyarakat dan pelaku menjadi penting dalam usaha perbaikan, rekonsiliasi dan penjaminan keberlangsungan usaha perbaikan tersebut.

Pasal 1 angka 6 UndangUndang Nomor 11 Tahun 2012 tentang Sistem Peradilan Pidana Anak telah menggunakan istilah "keadilan restoratif" yang berbunyi sebagai berikut : "Keadilan Restoratif adalah penyelesaian perkara tindak pidana dengan melibatkan pelaku, korban, keluarga pelaku/korban, dan pihak lain yang terkait untuk bersamasama mencari penyelesaian yang adil dengan menekankan pemulihan kembali pada keadaan semula, dan bukan pembalasan". Penyelesaian perkara pidana dengan menggunakan pendekatan restorative justice pada dasarnya terfokus pada upaya menstransformasikan kesalahan yang dilakukan pelaku dengan upaya perbaikan. Termasuk dalam upaya ini adalah perbaikan hubungan antara pihak yang terkait dengan peristiwa tersebut. Hal ini diimplementasikan dengan adanya perbuatan yang merupakan gambaran dari perubahan sikap para pihak dalam upaya mencapai tujuan bersama yaitu perbaikan.
Secara konseptual, restorative justice berisi gagasan-gagasan dan prinsip-prinsip sebagai berikut:

a. Membangun partispasi bersama antara pelaku, korban dan kelompok masyarakat menyelesaikan suatu peristiwa atau tindak pidana. Menempatkan pelaku, korban, dan masyarakat sebagai "stakeholders" yang bekerjasama dan langsung berusaha menemukan penyelesaian yang dipandang adil bagi semua pihak (win-win solution).

b. Mendorong pelaku bertanggungjawab terhadap korban atas peristiwa atau tindak pidana yang telah menimbulkan cedera, atau kerugian terhadap korban. Selanjutnya membangun tanggung jawab tidak mengulangi lagi perbuatan pidana yang pernah dilakukannya.

c. Menempatkan peristiwa atau tindak pidana tidak terutama sebagai suatu bentuk pelanggaran hukum, melainkan sebegai pelanggaran oleh seseorang (sekelompok orang) terhadap seseorang (sekelompok orang). Karena itu sudah semestinya pelaku diarahkan pada pertanggungjawaban terhadap korban, bukan mengutamakan pertanggungjawaban hukum.

d. Mendorong menyelesaikan suatu peristiwa atau tindak pidana dengan cara-cara yang lebih informal dan personal, daripada penyelesaian dengan cara-cara beracara yang formal (kaku) dan impersonal.

Secara lebih rinci Muladi menyatakan bahwa restorative justice model mempunyai beberapa karakteristik yaitu :

a. Kejahatan dirumuskan sebagai pelanggaran seorang terhadap 
orang lain dan diakui sebagai konflik;

b. Titik perhatian pada pemecahan masalah pertanggungjawaban dan kewajiban pada masa depan;

c. Sifat normatif dibangun atas dasar dialog dan negosiasi;

d. Restitusi sebagai sarana perbaikan para pihak, rekonsiliasi dan restorasi sebagai tujuan utama; e. Keadilan dirumuskan sebagai hubungan-hubungan hak, dinilai atas dasar hasil;

f. Sasaran perhatian pada perbaikan kerugian sosial;

g. Masyarakat merupakan fasilitator di dalam proses restoratif;

h. Peran korban dan pelaku tindak pidana diakui, baik dalam masalah maupun penyelesaian hak-hak dan kebutuhan korban. Pelaku tindak pidana didorong untuk bertanggung jawab;

i. Pertanggungjawaban si pelaku dirumuskan sebagai dampak pemahaman terhadap perbuatan dan untuk membantu memutuskan yang terbaik;

j. Tindak pidana dipahami dalam konteks menyeluruh, moral, sosial dan ekonomis; dan

k. Stigma dapat dihapus melalui tindakan restoratif (Muladi;2005).

Restorative justice mengembalikan konflik kepada pihak-pihak yang paling terkena pengaruh yaitu korban, pelaku dan kepentingan komunitas mereka dan memberikan keutamaan pada kepentingankepentingan mereka. Restorative justice juga menekankan pada hak asasi manusia dan kebutuhan untuk mengenali dampak dari ketidakadilan sosial dan dalam caracara yang sederhana untuk mengembalikan mereka daripada secara sederhana memberikan pelaku keadilan formal atau hukum dan korban tidak mendapatkan keadilan apapun. Kemudian restorative justice juga mengupayakan unfuk merestore keamanan korban penghormatan pribadi, martabat, dan yang lebih penting adalah sense of control.

Landasan filosofis restorative justice adalah perbaikan keadaan korban memaafkan perbuatan pelaku dan keikhlasan korban serta mengembalikan pelaku pada masyarakat. Hal ini sebagaimana yang dikemukakan oleh Consedine berikut ini :

We need to discover a philosophy thnt moves from punishment to reconcilitiation, from vengeance against offender to healing for victims, from negativity arul destructiveness to healing forgweness and mercy. That philosophical base is restorative juctice. A positive philoshopy that embraces a wide range of human emotiors, including healing, forgiveness, mercy and reconciliation, as well as sanction where appropriate, has much to offer (Jim;2003).

(Terjemahan bebas: Kita perlu menemukan sebuah filosofi yang bergerak dari hukuman untuk rekonsiliasi, dari balas dendam terhadap pelaku untuk pemulihan bagi korban dari negatif dan destruktif untuk pemulihan, pengampunan dan belas kasihan. Itulah dasar filosofis keadilan restoratif. Sebuah filosofi positif yang mencakup berbagi emosi manusia, termasuk pemulihan, pengampunan, dan rekonsiliasi serta sanksi jika diperlukan, yang menawarkan banyak hal). Restorative justice sebagai konsep pemidanaan bermaksud menemukan jalan menegakkan sistem pemidanaan yang lebih adil dan berimbang. Misalnya, antara 
kepentingan pelaku dan korban. Sistem pemidanaan yang berlaku saat itu kurang memperhatikan kepentingan korban. Selain kepentingan korban, dalam konsep restoratif justice menyangkut juga kepentingan pelaku dan kewajiban pelaku, yaitu agar pelaku kembali menjadi warga yang bertanggungjawab, baik terhadap korban, keluarganya (seperti orang tuanya), dan masyarakat sekelilingnya.

Sementara itu Satjipto Raharjo berpendapat bahwa "Hukum bukanlah sekedar logika semata karena lebih dari itu hukum merupakan ilmu sebenarnya, juga melihat adanya kaitan dengan halhal di belakang hukum" Keinginan untuk melihat logika sosial daripada logika hukum atau perundang-undangan, yang seharusnya selalu dimaknai sehingga selalu up to date. Dengan kata lain hukum selalu bergerak dan menyesuaikan dengan perkembangan masyarakat. Sanksi merupakan metode dalam mereaksi adanya ketidakseimbangan yang diakibatkan oleh perbuatan yang melanggar norma yang berlaku dalam masyarakat. Sanksi merupakan karakter pokok dari adanya pengakuan terhadap norma yang berlaku.

Sanksi menjadi pembatas tindakan seseorang dalam sistem sosial yang berlaku. Sanksi merupakan cerminan dari ketidakseimbangan tatanan sosial sebagai akibat adanya tindakan seseorang yang dipandang sebagai tindakan yang patologis dalam ukuran norma yang berlaku dalam masyarakat. Sanksi secara katagoris, ada yang dimaksudkan untuk mencegah agar orang tidak melakukan kejahatan. Sanksi juga dimaksudkan sebagai konsekuensi logis untuk memberikan beban menanggung kerugian atau risiko akibat perbuatan yang dilakukan seseorang. Sanksi dimaksudkan pula sebagai metode untuk menjerakan atau membalaskan kerugian atau penderitaan akibat dari perbuatan seseorang (detterence effect).

Konsep sanksi berkembang pada fase tidak lagi bersifat menjerakan atau membalaskan, atau bersifat sebagai upaya mengganti kerugian, fase perkembangan sanksi mengarah kepada memulihkan terhadap keseimbangan yang terganggu akibat adanya pelanggaran terhadap keseimbangan tatanan sosial (restorative). Sumber-sumber pencemaran perairan dan lautan dapat di kelompokkan menjadi tujuh kelas, yaitu : industri, limbah cair pemukiman, limbah cair perkotaan, pertambangan, pelayaran, pertanian, dan perikanan budidaya. Adapun perbedaan definisi mengenai pencemaran dan perusakan menurut UU No. 32 Tahun 2009 sebagai berikut :

Definisi pencemaran lingkungan hidup menurut Pasal 1 ayat (14) adalah masuk atau dimasukkannya mahkluk hidup, zat, energi dan/atau komponen lain ke dalam lingkungan hidup oleh kegiatan manusia sehingga melampaui baku mutu lingkungan hidup yang telah ditetapkan.

Definisi perusakan lingkungan menurut Pasal 1 ayat (16) adalah tindakan orang yang menimbulkan perubahan-perubahan langsung atau tidak langsung terhadap sifat fisik, kimia, dan/atau hayati lingkungan hidup sehingga melampaui kriteria baku kerusakan lingkungan hidup. 
Darmono mempunyai pendapat mengenai pengertian pencemaran adalah segala bentuk perubahan alam dan iklim yang ada di bumi akibat kegiatan manusia yang tidak dikehendaki oleh alam. Kegiatan ini seperti halnya penebangan hutan secara illegal atau membakar hutan lahan pertanian. Palar, mendefinisikan pencemaran lingkungan adakah proses perubahan ekosistem baik secara fisik, kimia, atau perilaku biologis yang bisa mengganggu kehidupan manusia karena dinilai dapat merusak sumberdaya yang ada di alam yang ada di bumi, bahkan keadaan ini dapat menyebabkan bencana alam.

Wardhana, menurutnya definisi dari sumber pencemaran adalah setiap bentuk kegiatan yang dilakukan manusia dalam membuang bahan pencemar, baik berbentuk padat, gas, cair atau partikel tersuspensi dalam kadar tertentu sehingga dapat lingkungan. Menurut peneliti, pencemaran lingkungan adalah suatu komponen yang dapat melampaui baku mutu lingkungan hidup yang telah di tetapkan. Peraturan hukum yang melandasi mengenai pencemaran minyak di Teluk Balikpapan yaitu UndangUndang Republik Indonesia No. 32 Tahun 2009 tentang Perlindungan dan Pengelolaan Lingkungan Hidup, Undang-Undang Republik Indonesia No. 32 Tahun 2014 tentang Kelautan, Peraturan Pemerintah Republik Indonesia No. 101 Tahun 2014 tentang B3 (Bahan, Berbahaya, dan Beracun).

Bentuk pertanggungjawaban pidana terhadap pelaku tindak pidana pencemaran minyak di Teluk Balikpapan untuk badan hukumnya diatur dalam Undang-
Undang Republilk Indonesia No. 32 Tahun 2009 pasal 88, sedangkan untuk perseorangannya dikenakan pasal 99 ayat 3 yaitu dengan ancaman pidana paling singkat 3 (tiga) tahun dan paling lama 9 (Sembilan) tahun dan denda paling sedikit Rp. 3.000.000.000,00 (tiga miliar rupiah) dan paling banyka Rp. 9.000.000.000,00 (sembilan miliar rupiah).

Untuk mengetahui suatu aturan hukum pidana sudah memberikan perlindungan hukum terhadap korban atau belum tidak dapat dilepaskan dari aturan mengenai sanksi pidana. Sedangkan sanksi pidana, merupakan komponen hukum pidana dari keseluruhan sistem hukum pidana disamping tindak pidana dan kesalahan yang pada hakikatnya merupakan sistem pemidanaan. Menurut Hulsman bahwa sistem pemidanaan (the sentencing system) adalah "aturan perundang-undangan yang berhubungan dengan sanksi pidana dan pemidanaan" (the statutory rules relating to penal sanctions and punishment) (L.H.C. Hulsman). Dengan demikian mengenai bentuk perlindungan hukum terhadap korban secara in abstracto dapat diketahui dari formulasi tindak pidana nya, pertanggungjawaban pidananya dan jenis sanksi pidananya. Dari formulasi mengenai tindak pidana dapat diketahui tentang perbuatan apa yang dilarang dan diancam pidana, kemudian dari perbuatan tersebut akan diketahui sanksi apa yang diancamkan terhadap pelaku. Bentuk pertanggungjawaban pelaku tidak dapat dilepaskan dari adanya kesalahan atau tidak dari si pelaku. Untuk itulah sanksi pidana secara bertahap mengalami pembaharuan 
demi memberikan perlindungan kepada korban.

\section{Kesimpulan}

Penambahan sanksi restitusi atau kompensasi juga perlu diterapkan pada undang-undang lingkungan hidup terutama apabila pelaku tindak pidana lingkungan hidup korporasi. Dalam undangundang tersebut juga dimuat mengenai cara dan besarnya nilai ganti rugi pada penjelasan undangundang. Undang-undang lingkungan hidup UU No 32 tahun 2009 belum memberikan perlindungan hukum kepada korban. Dalam UUPPLH belum tampak adanya aturan mengenai sanksi pidana yang memberikan perlindungan hukum kepada korban secara restoratif, sanksi yang ada masih berupa sanksi pidana penjara atau denda.

\section{Daftar Pustaka}

Buku

Ali, Chidir, 1992. Badan Hukum, Alumni, Bandung.

Amsyari, Fuad, 1997. PrinsipPrinsip Masalah Pencemaran Lingkungan, Ghalia Indonesia, Jakarta.

Arief, Barda Nawawi, 1996. Bunga Rampai Kebijakan Hukum Pidana, Citra Aditya Bakti, Bandung. 1998. Beberapa Aspek Penegakan dan Pengembangan Hukum Pidana, Citra Aditya Bakti, Bandung.

Fuady, Munir, 2013. Teori-Teori Besar (Grand Theory) dalam Hukum, Kencana, Jakarta.

Hamdan, M., 2000. Tindak Pidana Pencemaran Lingkungan Hidup, Mandar Maju, Bandung.
Hardjasoemantri, Koesnadi, 1999. Hukum Tata Lingkungan, Gajah Madaniversity Press, Yogyakarta.

Koeswadji, Hermin Hadiati, 1993. Hukum Pidana Lingkungan, Citra Aditya Bakti, Bandung.

Kristian, 2014. Hukum Korporasi Ditinjau dalam The United Nations Global Compact (Suatu Pengantar), Nuansa Aulia, Bandung.

Lotulung, Paulus E., 1993. Penegakan Hukum Lingkungan oleh Hakim Perdata, Citra Aditya Bakti, Bandung.

Muladi dan Priyanto, Dwija, 1991. Pertanggungjawaban Koporasi dalam Hukum Pidana, STH, Bandung.

Muladi, 1997. Hak Asasi Manusia, Politik dan Sistem Peradilan Pidana, Badan Penerbit Universitas Diponegoro, Semarang.

Silalahi, Daud, 1992. Hukum Lingkungan dalam Sistem Penegakan Hukum Lingkungan Indonesia, Alumni, Bandung.

Sudarto, 1990. Hukum Pidana I, Fakultas Hukum Universitas Diponegoro, Semarang.

Hukum 2003. Penegakan
Terintegrasi Kongep \&
Langkah-langkah
Pengaktualisasian, Indonesian
Center for Environmental Law
(ICEL).

Jurnal, Majalah dan Internet

Arif, Barda Nawawi. Pencegahan Dan Penanggulangan Kejahatan, Makalah pada Diklat Aparatur Penegak Hukum. Pusdiklat 
Depkumdang Cinere, Jakarta, 28 Januari 2000.

Tempo, Mengejar Ganti Rugi Tumpahan Montara, 8 Juni 2014.

http:/ / penegakanhukum.menlh.go. id., Berharap UU Lingkungan Hidup Tegak Lurus, diakses 8 Juni 2018.

http:/ / www.Mongabay.co.id/2013, Kasus Kejahatan Lingkungan Hidup Ditangani dengan Penegakan Hukum Terpadu, diakses 6 Agustus 2018.

http:/ / www.mongabay.co.id/2017 /10/30, L.P. Hutahaea, Perlu Upaya Serius Mencegah Tumpahan Minyak di Laut, diakses 13 November 2018, 18.00 WIB.

http:/ / www.mongabay.co.id/2018 /04/10/, Raynaldo Sembiring, Tumpahan Minyak di Teluk Balikpapan, diakses 13 November 2018, 18.10 WIB. 